\title{
The Effect of Service Quality and Price on Customer Satisfaction and Repurchase Intention (Case Study at Crown Prince Hotel Surabaya)
}

\author{
Tri Wahyu Putra Susanto*, I Nyoman Sudapet, Hamzah Denny Subagyo, \& Joko Suyono \\ Faculty of Economics and Business, Narotama University, Surabaya, Indonesia
}

\begin{abstract}
The aim of this study: (1) to analyze the effect of Service Quality on Customer Satisfaction, (2) to analyze the effect of prices on Customer Satisfaction, (3) to analyze the effect of Service Quality on Repurchase Intention, (4) to analyze the effect of Price on Repurchase Intention, (5) to analyze the effect of Customer Satisfaction on Repurchase intention. This research is quantitative research. The population and samples were distributed to 86 respondents. Data collection techniques using a questionnaire. The data analysis used is Convergent Validity, Discriminant Validity, Reliability and Average Variance Extracted (AVE). The results of the study show that the influence of Service Quality variable (X1) on Customer Satisfaction (Y1) is significant at 0,000. Customer Quality Variable (X1) is not significant with the Repurchase Intention (Y2) variable of 0.225. Based on the correlation for the Price variable (X2) to customer satisfaction (Y1) of 0.020. And the price variable (X2) is significant with the Repurchase Intention (Y2) variable of 0,000. And the Customer Satisfaction variable (Y1) is significant with the Repurchase Intention (Y2) variable of 0,000 . The results of this study indicate that, compared to service quality, Price has a stronger influence on customer satisfaction, which leads to a Buyback Interest.
\end{abstract}

Keywords: Service Quality; Price; Customer Satisfaction; Repurchase Intention.

\section{Introduction}

Quality is a dynamic condition that relates to products, services, people, processes and environments that meet or exceed expectations (Tjiptono, 2004). service quality that is felt to be very important for the success of the organization because of the direct relationship with customer satisfaction and behavioral intention. This organization provides superior service also experiences a high level of customer satisfaction and profitable word of mouth. Companies must place an orientation on customer satisfaction as the main goal. This is reflected in the increasing number of companies that include their commitment to customer satisfaction in their mission statements and advertisements. The main key for the company to win the competition is to provide value and satisfaction to customers through the delivery of quality products and services customer satisfaction or dissatisfaction is the customer's response to perceived mismatches between previous expectations and the actual performance of the product. Customer satisfaction is defined as post-consumption evaluation that an alternative chosen at least meets or exceeds customer expectations (Tjiptono, 2004). If a company provides a product or service that is of good quality, then it is expected to be able to meet customer expectations and ultimately be able to provide maximum value and create satisfaction for customers compared to competitors who are competitively priced. In industries that enter maturity (mature), service quality has a contribution to the company that differentiates companies from competition (Simon, et al, 2005). One way to differentiate a service company from competition is the consistent delivery of highquality services (Kotler, 2000).

The key is to meet or exceed the expectations of customer service quality. Price (price) is the sum of all values given by the customer to benefit from owning or using a product or service (Kotler, 2008). In the process of pricing, it

\footnotetext{
* Corresponding author.

E-mail address: wahyu.zanker@gmail.com (Tri Wahyu Putra Susanto)
} 
should be done in accordance with company goals and marketing. Pricing is done by the company based on many considerations. If the consumer accepts an offer, the price is correct. If they refuse, usually the price will be quickly replaced or if necessary the product can be withdrawn from the market. One of the effects of buying products is repurchase intention or interest in repurchasing. Helier et al. (2003) stated that repurchase intention is a planned decision of someone to repurchase certain services, taking into account the situation that occurs and the level of success. This repurchase includes 2 characteristics, namely intention (intention) and behavior (behavior). This repurchase intention is closely related to the attitude of the consumer towards the object and the attitude of the consumer towards the behavior previous. Akhter's research (2010) found that satisfaction is not directly related to repurchase, but it is not true that consumer satisfaction affects repurchase behavior when viewed from psychological research where satisfaction encourages intense and intense behavior. Therefore, it cannot be denied that repurchase is one indicator of customer satisfaction and also the effect of purchases. The focus of this study was conducted on one hotel in Surabaya, namely the Crown Prince Hotel where the purpose of this study was to analyze the variable variables studied by researchers.

\section{Literature Review}

\subsection{Service Quality (X1)}

Quality is a dynamic condition that influences products, services, people, processes and environments that meet or exceed expectations (Tjiptono, 2001). So that the definition of service quality can be interpreted as an effort to fulfill the needs and desires of consumers and the accuracy of delivery in balancing consumer expectations (tjiptono, 2007). Service quality can be known by comparing consumers' perceptions of services they actually receive / obtain with service that they actually expect / want from the service attributes of a company. If the service is perceived or perceived as expected, the quality of service is perceived as good and satisfying, if the service received exceeds consumer expectations, then the quality of service is perceived as very good and quality. Conversely, if the servicereceived is lower than expected, then the service quality is perceived poorly

Hypothesis 1: Service Quality has a significant effect on Customer Satisfaction.

Hypothesis 2: Service Quality has a negative or insignificant effect on Repurchase Intention.

\subsection{Price $(X 2)$}

According to Kotler and Armstrong (2013: 151), a sum of money charged on an item or service or amount of the value of money exchanged by consumers for the benefits of owning or using the product or service. According to Philip Kotler (2012: 132): Price is the amount of money customers have to pay for that product. According to Tjiptono (2005), price is a monetary unit or other measure including goods and other services that are exchanged in order to obtain ownership rights or users of an item and service.

Hypothesis 3: Price has a significant effect on Customer Satisfaction.

Hypothesis 4: Price has a significant effect on Repurchase Intention.

\subsection{Customer Satisfaction (Y1)}

According to Kotler \& Armstrong (2012: 36), customer value is a customer comparison between all profits and all costs that must be paid to receive the offer given. The amount of customer costs is a group of costs used in assessing, obtaining and using a product or service. Because customer satisfaction is very dependent on the perception and expectations of customers, then as a product supplier need to know the factors that influence it. Satisfaction is the feeling of being happy or disappointed by someone who arises because it compares the perceived work of the product (or result) to their expectations "(kottler, 2010: 138). Consumer satisfaction according to Engel et al (1990: 45) is "after-purchase evaluation where at least it gives results equal to or exceeds consumer expectations. While dissatisfaction arises when the results obtained do not meet consumer expectations.

Hypothesis 5: Customer Satisfaction has a significant effect on Repurchase Intention. 


\subsection{Repurchase Intention (Y2)}

One of the effects of buying a product is repurchase or repurchase. Repurchase Intention is the intention to repurchase a product twice or more, both for the same and different products (Zeng, Zuahao, Rong, \& Zhilin, 2009). This repurchase includes 2 characteristics, namely intention (intention) and behavior (behavior). This repurchase intention is closely related to consumer attitudes towards objects and consumer attitudes toward previous behavior. Akhter's research (2010) found that satisfaction is not directly related to repurchase, but it is not wrong that consumer satisfaction influences repurchase behavior when viewed from psychological research where satisfaction encourages intention and intention to encourage behavior. Therefore, it cannot be denied that repurchase is one indicator of satisfaction and also the effect of purchases. Chang, Lee, Chien, Huang and Chen (2010) say that there is a positive relationship between consumer experience of a product and the tendency of consumers to return to purchases the products evaluated are good. Consumer intention in online purchasing is the activity of consumers to make purchases in an online store. Theory of Reasoned Action developed by Icek Ajzen and Martin Fishbein in 1980 (in Jogiyanto, 2007) assumes that consumers consciously consider all information on existing alternatives and finally will choose an alternative that can provide the consequences.

Hawkins \& Mothersbaugh (2010) add consumers can continue to repurchase even though they have no emotional attachment to a product or item. Hawkins \& Mothersbaugh (2001) also revealed that consumers who are dissatisfied with previous purchases can repurchase with a number of factors such as no substitute items, difficulty making an exit, no substitute items and various other facilities provided.

\section{Methods}

Research using a quantitative approach is a method based on the philosopher's positivist, used to examine certain populations or samples. Data collection uses research instruments, quantitative / statistical data analysis. With the aim of testing what has been set (Sugiyono, 2008). The variable of this study consisted of independent variables of Service Quality and Price, intervening variables of Customer Satisfaction and dependent variables, namely Buyback Interest. The population of this study were consumers of the Crown Prince Surabaya Hotel with 86 respondents. Data analysis techniques used PLS (Partial Least Square).

\subsection{Structural Model (Inner Model)}

Ghozali (2015) inner model which is sometimes referred to as (inner relations, structural model, and substantive theory) illustrates the relationship between latent variables based on the substantive theory.

\subsection{Measurement Model (Outer Model)}

Ghozali (2015) The outer model shows that each indicator block is related to its latent variables.

\subsection{Weight Relations}

Ghozali (2015) Outer and Inner models provide specifications followed in PLS algorithm estimation.

\subsection{Evaluation of Structural Models (Inner Model)}

Structural models were evacuated with PLS. By using R-Square for endogenous (dependent) latent variables. The interpretation is the same as the interpretation in OLS regression. Changes in the R-Squares value can be used to assess the effect of exogenous latent variables (independent) on endogenous variables (dependent) whether they have substantive effects. Evaluation of Reflexive Indicator Measurement Model (Outer Model) According to Ghozali and Aprilia (2016: p. 37-38) Convergent validity of the measurement model with a reflective indicator is assessed based on the value of loading factors of each indicator forming a latent construct. A construct is said to have good convergent validity if the loading factor is more than 0.70 and is significant. But for researchers in the early stages of 
developing a measurement scale, the loading values of 0.5 to 0.6 are considered sufficient.

Discriminant validity measurement models with reflective indicators are assessed by comparing the square root value of average variance extracted (AVE) of each latent construct with the correlation between constructs related to other constructs in the model. If the AVE square root value of each construct is greater than the correlation value between constructs and other constructs in the model, then it has good discriminant validity.

\section{Result and Discussions}

\subsection{Data Analysis and Hypothesis Test Data Analysis}

In this study the researcher used dat PLS analysis technique using Smart PLS (Partial Least Squares) Software which is a powerful and often referred to as Soft Modeling because it negates the assumption of OLS (Ordinary Least Squares) regression assumptions, like data must be normally distributed multivariate and there is no problem of multicoloniality between variables, wold, 1985 in the book (Ghozali \& Latan, 2015).

\section{a. Convergent Validity}

Table 1. Outer loading (Measurement Model)

\begin{tabular}{ccccc}
\hline & $\mathrm{X} 1$ & $\mathrm{X} 2$ & $\mathrm{Y} 1$ & $\mathrm{Y} 2$ \\
\hline $\mathrm{X} 1.1$ & 0.811 & & & \\
$\mathrm{X} 1.2$ & 0.901 & & & \\
$\mathrm{X} 1.3$ & 0.826 & & & \\
$\mathrm{X} 1.4$ & 0.563 & & & \\
$\mathrm{X} 1.5$ & 0.607 & & & \\
$\mathrm{X} 2.1$ & & 0.923 & & \\
$\mathrm{X} 2.2$ & & 0.845 & & \\
$\mathrm{X} 2.3$ & & 0.886 & & \\
$\mathrm{X} 2.4$ & & 0.897 & & \\
$\mathrm{Y} 1.1$ & & & 0.876 & \\
$\mathrm{Y} 1.2$ & & & 0.892 & \\
$\mathrm{Y} 1.3$ & & & 0.898 & \\
$\mathrm{Y} 2.1$ & & & & 0.936 \\
$\mathrm{Y} 2.2$ & & & & 0.927 \\
$\mathrm{Y} 2.3$ & & & & 0.857 \\
\hline
\end{tabular}

The results of processing using Smart PLS can be seen from the table 1, the value of the outer model or correlation between constructs and latent variables has met convergent validity because the loading factor value in the table above is not below the loading factor limit value of 0.50 .

\section{b. Discriminant Validity}

Discriminant validity is done to ensure that each concept of each latent variable is different from the other variables. The model has good discriminant validity if each loading value of each indicator of a latent variable has the highest loading value with other loading values for other latent variables. The results of discriminant validity testers are obtained as follows: 
Table 2. Discriminant Validity Value (Cross Loading)

\begin{tabular}{ccccc}
\hline & $\mathrm{X} 1$ & $\mathrm{X} 2$ & $\mathrm{Y} 1$ & $\mathrm{Y} 2$ \\
\hline $\mathrm{X} 1.1$ & $\mathbf{0 . 8 1 1}$ & 0.434 & 0.639 & 0.601 \\
$\mathrm{X} 1.2$ & $\mathbf{0 . 9 0 1}$ & 0.661 & 0.607 & 0.607 \\
$\mathrm{X} 1.3$ & $\mathbf{0 . 8 2 6}$ & 0.680 & 0.439 & 0.445 \\
$\mathrm{X} 1.4$ & $\mathbf{0 . 5 6 3}$ & 0.249 & 0.368 & 0.087 \\
$\mathrm{X} 1.5$ & $\mathbf{0 . 6 0 7}$ & 0.432 & 0.518 & 0.461 \\
$\mathrm{X} 2.1$ & 0.605 & $\mathbf{0 . 9 2 3}$ & 0.598 & 0.673 \\
X2.2 & 0.694 & $\mathbf{0 . 8 4 5}$ & 0.502 & 0.464 \\
X2.3 & 0.461 & $\mathbf{0 . 8 8 6}$ & 0.468 & 0.575 \\
X2.4 & 0.642 & $\mathbf{0 . 8 9 7}$ & 0.542 & 0.605 \\
$\mathrm{Y} 1.1$ & 0.569 & 0.454 & $\mathbf{0 . 8 7 6}$ & 0.716 \\
$\mathrm{Y} 1.2$ & 0.576 & 0.528 & $\mathbf{0 . 8 9 2}$ & 0.816 \\
$\mathrm{Y} 1.3$ & 0.721 & 0.598 & $\mathbf{0 . 8 9 8}$ & 0.821 \\
$\mathrm{Y} 2.1$ & 0.595 & 0.641 & 0.880 & $\mathbf{0 . 9 3 6}$ \\
$\mathrm{Y} 2.2$ & 0.745 & 0.556 & 0.840 & $\mathbf{0 . 9 2 7}$ \\
$\mathrm{Y} 2.3$ & 0.386 & 0.597 & 0.671 & $\mathbf{0 . 8 5 7}$
\end{tabular}

From the table 2, it can be seen that the loading factor for each indicator dar each latent variable has a value of greatest loading factor if it is connected with other latent variables. This means that every latent variable has good discriminant validity.

\section{c. Evaluating Reliability and Average Extracted (AVE)}

Validity and reliability criteria can also be seen from the reliability value of a construct and the value of Average Variance Extracted (AVE) and each construct. Constructions are said to have high reliability if the value is 0.70 and AVE is above 0.50. In the table below, the Composite Reliability and AVE values for all variables are presented.

Table 3. Composive Reliability and AVE

\begin{tabular}{ccc}
\hline & Composite Reliability & Average Variance Extracted (AVE) \\
\hline $\mathrm{X} 1$ & 0.864 & 0.567 \\
$\mathrm{X} 2$ & 0.937 & 0.789 \\
$\mathrm{Y} 1$ & 0.919 & 0.790 \\
$\mathrm{Y} 2$ & 0.933 & 0.823 \\
\hline
\end{tabular}

Based on the table 3, it can be concluded that all constructs meet reliable criteria. This is indicated by the value of Composite Reliability above 0.70 and AVE above 0.50 as the recommended criteria. 


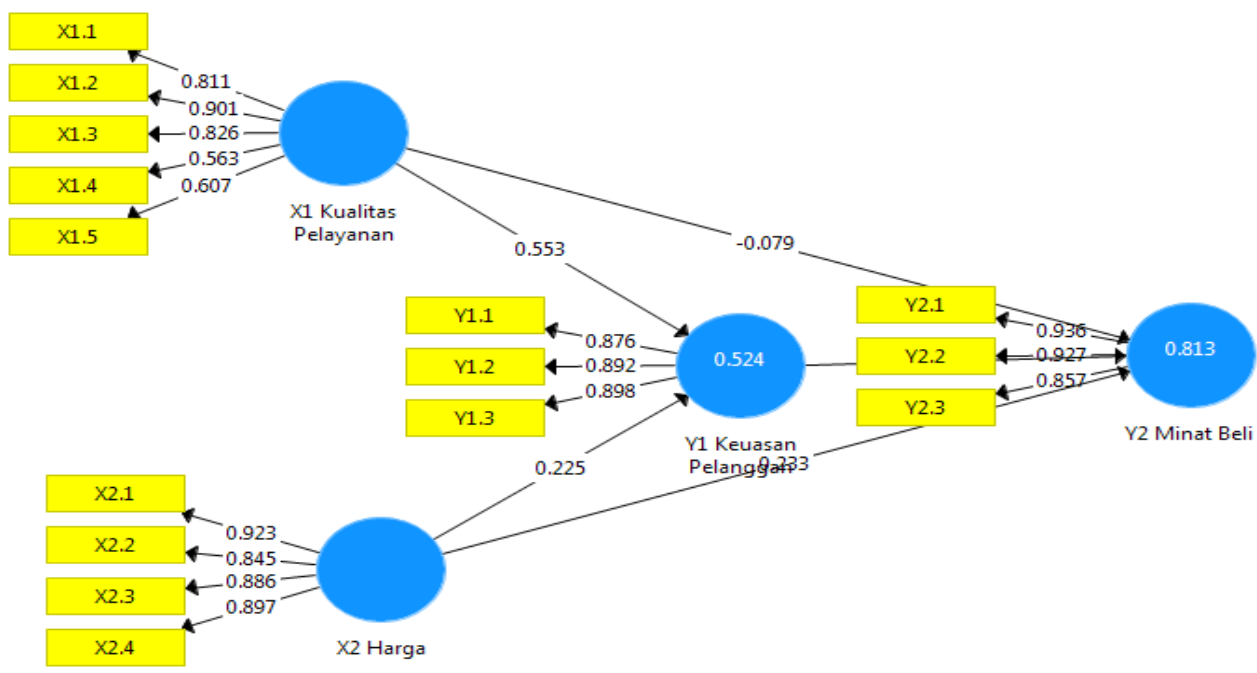

Fig. 1. Structural Models (in Indonesia)

Testing of inner models or structural models is done to see the relationship between constructs, significant values and $\mathrm{R}$-square of the research model. The structural model is evaluated by using the R-square for the dependent construct of the $t$ test and the significance of the structural path parameter coefficients. in assessing models with PLS are measured by looking at the R-square adjusted for each dependent latent variable. The table 4 is the result of adjusted adjusted R-square estimation using Smart PLS.

Table 4. Square Adjusted

\begin{tabular}{lc}
\hline & R Square Adjusted \\
\hline Customer Satisfaction (Y1) & $0.512(51.2 \%)$ \\
Repurchase Intention (Y2) & $0.806(80,6)$ \\
\hline
\end{tabular}

In this study consisted of 4 independent variables (free) as many as 2 variables namely Service Quality (X1 ), Price (X2), VAriabel intervening as much as 1 variable, namely Customer Satisfaction (Y1), And dependent variable as much as 1, namely Repurchase Intention (Y2).

Table 4 shows the value of R Square Adjusted for Customer Satisfaction variable (Y1) obtained 0.512 for the variable Repurchase Intention (Y2) obtained at 0.806 . These results indicate that $51.2 \%$ variable customer satisfaction (Y1) can be influenced by service quality (X1), and price (X2), while repurchase intention (Y2) can be influenced by variable Quality of Service (X1), Price (X2), and Customer Satisfaction (Y1) with a value of $80.6 \%$.

\subsection{Hypothesis}

Significance of the estimated parameters provides very useful information about the relationship between the research variables. The basis used in testing hypotheses is the value found in the output Path coefficent. The table 5 provides an estimated output for testing structural models. 
Table 5. Data processing sources with PLS

\begin{tabular}{lccccc}
\hline & $\begin{array}{c}\text { Original } \\
\text { Sample } \\
(\mathrm{O})\end{array}$ & $\begin{array}{c}\text { Sample } \\
\text { Mean (M) }\end{array}$ & $\begin{array}{c}\text { Standard } \\
\text { Deviation } \\
(\text { STDEV })\end{array}$ & $\begin{array}{c}\text { T Statistics } \\
(\mid \mathrm{O} / \text { STDEV })\end{array}$ & P Values \\
\hline$(\mathrm{X} 1)$-> (Y1) & 0.553 & 0.552 & 0.087 & 6,339 & 0.000 \\
$(\mathrm{X} 1)->(\mathrm{Y} 2)$ & -0.079 & -0.059 & 0.105 & 0.755 & 0.225 \\
$(\mathrm{X} 2)->(\mathrm{Y} 1)$ & 0.225 & 0.222 & 0.109 & 2,065 & 0.020 \\
$(\mathrm{X} 2)->(\mathrm{Y} 2)$ & 0.233 & 0.228 & 0.068 & 3,447 & 0.000 \\
$(\mathrm{Y} 1)->(\mathrm{Y} 2)$ & 0.802 & 0.796 & 0.064 & 12,537 & 0.000 \\
\hline
\end{tabular}

Testing the hypothesis will be done by Boostrapping to see T-statistics and P-values with a significant level Of 5\% (1.96). So that the acceptance criteria or rejection of the hypothesis is that HA is accepted and HO is rejected when the T-statistic shows $>1.96$ and to reject or accept the hypothesis using probability values, then HA will be accepted if Pvalue is $<0.05$. The results of testing with Boostrapping from PLS analysis are as follows:

\section{1) Testing of hypothesis 1 (Service Quality has a significant positive effect on Satisfaction Customer)}

The results of testing the first hypothesis shows that the effect of variable X1 on Y1 shows a T value of 6.399 with a $\mathrm{P}$-value of 0,000 . This value is greater than $\mathrm{T}$ table (1.96) and $\mathrm{P}$-value is smaller than 0.05 . This result means Customer Quality (X1) has a significant influence on Customer Satisfaction (Y1). This means that Hypothesis 1 is accepted.

\section{2) Testing of hypothesis 2 (Service Quality has a negative effect on Repurchase Intention)}

The results of testing the second hypothesis shows that the effect of the X1 variable on Y2 indicates a $\mathrm{T}$ value of 0.755 with a $\mathrm{P}$-value of 0.225 . This value is smaller than T table (1.96) and $\mathrm{P}$-value is greater than 0.05 . This result means Customer Quality (X1) has no significant effect on Repurchase Intention (Y2). This means that Hypothesis 2 is not acceptable.

\section{3) Testing of hypothesis 3 (Price has a significant positive effect on Customer Satisfaction)}

The results of testing the third hypothesis shows that the effect of variable X2 on Y1 indicates T value of 2.065 with a $\mathrm{P}$-value of 0.020 . This value is greater than $\mathrm{T}$ table (1.96) and P-value is smaller than 0.05 . This result means that Price (X2) has a significant influence on Customer Satisfaction (Y1). This means that Hypothesis 3 is acceptable.

\section{4) Testing of hypothesis 4 (Price has a significant positive Repurchase Intention)}

The results of testing the fourth hypothesis shows that the effect of the variable X2 on Y2 indicates a T value of 3.447 with a P-value of 0,000 . This value is greater than T table (1.96) and P-value is smaller than 0.05 . This result means that Price (X2) has a significant effect on the Repurchase Intention (Y2). This means that Hypothesis 4 is acceptable.

\section{5) Testing hypotheses 5 (Customer Satisfaction has a significant positive Repurchase Intention )}

BuybackThe results of the fifth hypothesis testing show that the effect of the variable Y1 on Y2 points to a T value of 12.537 with a $\mathrm{P}$-value of 0.000 . This value is greater than $\mathrm{T}$ table (1.96) and $\mathrm{P}$-value is smaller than 0.05 . This result means Customer Satisfaction (Y1) has a significant influence on the Repurchase Intention (Y2). This means that Hypothesis 5 is acceptable. 


\subsection{Discussion}

\section{a. Effect of Customer Quality (X1) on Customer Satisfaction (Y1)}

Based on the results of the analysis using smartPLS, it can be concluded that the construct of Customer Quality has a significant effect on the construct of Customer Satisfaction. This can be seen from the t value of 6.339. This value is greater than t table $(1,960)$. Thus, the H1 hypothesis in this study was accepted. This shows that good Customer Quality will cause customers to be satisfied with the services of the Crown Prince Hotel.

\section{b. Effect of Service Quality (X1) on Repurchase Interests (Y2)}

Based on the results of the analysis using smartPLS, it can be concluded that the construct of Customer Quality has no significant effect on the construct of Repurchase Intention. This can be seen from the $t$ value of 0.755 . This value is smaller than $t$ table $(1,960)$. Thus, the H2 hypothesis in this study is not acceptable. This shows that Customer Quality has not guaranteed to make Crown Prince customers make return visits.

\section{c. Price Influence (X2) on Customer Satisfaction (Y1)}

Based on the results of the analysis using smartPLS, it can be concluded that the price construct has a significant effect onthe construct of Customer Satisfaction. This can be seen from the $t$ value of 2,065. This value is greater than $t$ table $(1,960)$. Thus, the H3 hypothesis in this study was accepted. This shows that the price given by Crown Prince causes customers to be satisfied.

\section{d. Effect of Customer Satisfaction (Y1) on Repurchase Interests (Y2)}

Based on the results of the analysis using smartPLS, it can be concluded that the construct of Customer Satisfaction has a significant effect on the construct of Repurchase Intention. This can be seen from $t$ at 12,537. This value is greater than t table $(1,960)$. Thus, the H5 hypothesis in this study was accepted. This shows that satisfied customers are very influential to be interested in repurchasing at Crown Prince Hotel.

\section{Conclusions}

Based on the problems that have been formulated, the results of the analysis and testing of hypotheses that have been carried out in the previous chapter, then conclusions can be drawn as follows:

(1) The results of data processing show a significant influence between variables of Service Quality on Customer Satisfaction with a P-value of 0,000 and a T-table value of 6,339. Based on the results of processing these data it shows that good service quality will cause customers to be satisfied with Crown Prince.

(2) The results of data processing show that there is no significant effect between the variables of Service Quality on Repurchase Intention with a P-value of 0.225 and a T-table value of 0.775 . Based on the results of processing these data it shows that Service Quality has not guaranteed to make Crown Prince consumers make return visits.

(3) The results of data processing show that there is a significant influence between the Price variable on Customer Satisfaction with a P-value of 0.020 and a T-table value of 2.065. Based on the results of processing the data this shows that the price given by Crown Prince causes customers to be satisfied.

(4) The results of data processing show that there is a significant influence between the price variable and the Repurchase Intention with a P-value of 0,000 and a T-table value of 3,447. Based on the results of data processing, this shows that competitive prices cause consumers to want to re-transact or make repeat purchases at Crown Prince.

(5) The results of data processing show that there is a significant influence between the variable Customer Satisfaction with the Repurchase Intention with a P-value of 0,000 and a T-table value of 12,537. Based on the results of data processing, this shows that satisfied customers are very influential to be interested in repurchasing 
at Crown Prince Hotel.

\section{References}

Abdul Aziz, T. D. (2016). Perencanaan Strategis Sistem Informasi dan Teknologi Informasi di Dinas Pendapatan, Pengelolaan Keuangan dan Aset Kabupaten Kampar (Model Strategis Ward and Peppard). ISSN 2460-738X. Jurnal CoreIT, 2(2), 1-7.

Agustina Shinta, M. P. (2002). Manajemen Pemasaran (terjemahan). Edisi Millenium, Jilid 1. https://doi.org/10.1016/j.electacta.2014.10.067

Ahmed, I., Nawaz, M. M., Usman, A., Shaukat, M. Z., \& Ahmed, N. (2010). A mediation of customer satisfaction relationship between service quality and repurchase intentions for the telecom sector in Pakistan: A case study of university students, 4(16), 3457-3462.

Arsyanti, N. M., Rahayu, S., \& Astuti, T. (2016). Analisis Pengaruh Kualitas Produk , Kualitas Layanan dan Keragaman Produk Terhadap Kepuasan Pelanggan Serta Dampaknya Terhadap Minat Beli Ulang ( Studi pada Toko Online Shopastelle, Semarang ), 5, 1-11.

Bahari, E. (2014a). Analisis Strategic Peningkatan Nilai Ekonomi Sawit Di Provinsi Lampung. Proseding Seminar Bisnis \& Teknologi ISSN : 2407-6171, 15-16.

Bahari, E. (2014b). No Title. In SEMBISTEK 2014 IBI DARMAJAYA (pp. 1-30).

Bisnis, P., Buah, A., \& Di, N. (2017). Prodi Teknik Industri, Universitas Putera Batam, 51-58.

Bisnis, P. M., Manajemen, P. S., Petra, U. K., \& Siwalankerto, J. (2013). Manajemen Dan Pengembangan Sumber Daya Manusia Pada Usaha Corrugated Cartons and Boxes Pt . Zxc. Agora, 1(1).

Chairuna, D., Lisanti, Y., \& Kuncoro, E. A. (n.d.). Penerapan E-Customer Relationship Management Pada Taman Kanak-Kanak Hanifa, (9), 291-306.

Chinomona, R. (2014). Does Customer Satisfaction Lead to Customer Trust, Loyalty and Repurchase Intention of Local Store Brands? The Case of Gauteng Province of South Africa, 5(9), 23-32. https://doi.org/10.5901/mjss.2014.v5n9p23

Chinomona, R., \& Sandada, M. (2013). Customer Satisfaction , Trust and Loyalty as Predictors of Customer Intention to Re-Purchase South African Retailing Industry, 4(14), 437-446. https://doi.org/10.5901/mjss.2013.v4n14p437

Firatmadi, A., Jayabaya, U., Service, P. A., Harga, P., Pelanggan, K., \& Service, A. (2017). Journal of business studies, 2(2), 80-105.

Gunawan, R. D., Suryono, R. R., \& Purwanto, I. (2010). Analisa Perubahan Manajemen Dalam Implementasi Si / Ti Pada Perguruan Tinggi Abc. Seminar Nasional Aplikasi Teknologi Informasi, 2010(Snati), 1-6.

Huda, C., Pangestu, B., Lai, J., \& Teja, R. (2010). Analisis Dan Perancangan Data Warehouse Pada Pt Gajah Tunggal Prakarsa, (9), 437-448.

Kanzu, H. Al, \& Soesanto, H. (2016). PERCEIVED VALUE TERHADAP KEPUASAM RELIGIUS UNTUK MENINGKATKAN MINAT MENABUNG ULANG ( STUDI PADA BNI SYARIAH SEMARANG ), 5, 112.

Lee, H. S. (2017). Major Moderators Influencing the Relationships of Service Quality, Customer Satisfaction and Customer Loyalty, 9(2), 1-11. https://doi.org/10.5539/ass.v9n2p1

Ojo, O. (2010). The Relationship Between Service Quality and Customer Satisfaction in the Telecommunication Industry: Evidence From Nigeria, 1(1), 88-100.

Pada, N., Bank, P. T., Asia, C., \& Desembrianita, E. (2016). Vol. 01, No. 01. Tahun 2016 ISSN 2540-959X, 1(1), 30- 
38.

Pelayanan, K., Produk, K., \& Citra, D. A. N. (2016). 5(9), 5695-5721.

Ponorogo, K., Manajemen, P. S., \& Ekonomi, F. (2016). Pengaruh Persepsi Harga , Kualitas Pelayanan dan Citra Terhadap Niat Konsumen untuk Word of Mouth dengan Kepuasan sebagai Variabel Mediasi, 2(1).

Priangani, A. (2013). Memperkuat Manajemen Pemasaran Dalam Konteks Persaingan Global. Jurnal Kebangsaan, 2(4), 1-9.

Rahanatha, G. B. (2018). DAN KEPUASAN KONSUMEN TERHADAP NIAT MEMBELI KEMBALI I Made Arya Dharmayana 1 dan Bisnis Universitas Udayana, Bali 6(4), 2018-2046.

Rahman, M. S., Khan, A. H., \& Haque, M. (2017). A Conceptual Study on the Relationship between Service Quality towards Customer Satisfaction: Servqual and Gronroos 's Service Quality Model Perspective, 8(13), 201-210. https://doi.org/10.5539/ass.v8n13p201

Ramadhan, A. G., \& Santosa, S. B. (2017). Analisis Pengaruh Kualitas Produk, Kualitas Pelayanan , dan Citra Merek terhadap Minat Beli Ulang pada Sepatu Nike Running di Semarang melalui Kepuasan Pelanggan sebagai Variabel Intervening, 6, 1-12.

Razak, A., Baheri, J., \& Ramadhan, M. I. (2018). Pengaruh Kepuasan dan Kepercayaan terhadap Loyalitas Nasabah pada Bank Negara Indonesia ( BNI ) Cabang Kendari, 1(79), 10-20.

Slamet, A. S., Marimin, Arkeman, Y., \& Udin, F. (2011). Study of Performance Improvement for Highland Vegetables Supply Chain Management in West Java. Jurnal Agritech Fakultas Teknologi Pertanian UGM, 31(1), 60-70. Retrieved from http://jurnal-agritech.tp.ugm.ac.id/ojs/index.php/agritech/article/view/81/76

Supply Chain Council, Council, S. C., \& Supply Chain Council. (2008). SCOR® supply chain operations reference model. Supply Chain Operations Management (Vol. 11.0). https://doi.org/10.1108/09576059710815716

Surya Hakim, A. (2013). Strategi Knowledge Management pada PLN APJ Kediri: Studi Deskriptif strategi knowledge management dan Pengetahuan yang tersedia pada PLN APJ Kediri. Journal Unair, II, 1-17. Retrieved from http://journal.unair.ac.id/download-fullpapers-jurnal adyas.pdf

Yunitarini, R., Budi, P., \& Nurwarsito, H. (2012). Implementasi Perangkat Lunak Electronic Customer Relationship Management ( E-CRM ) dengan Metode Framework of Dynamic CRM. Jurnal EECCIS, 6(1), 83-90. 